\title{
The Analysis of Using Active Learning Technology in Institutions of Secondary Vocational Education
}

Tatyana Nikolaevna Bochkareva

Kazan Federal University, Elabuga Institute of KFU, Russia, tatyana-n-boch@bk.ru

Elvir Munirovich Akhmetshin

Kazan Federal University, Elabuga Institute of KFU, Russia, elvir@mail.ru

\section{Angelina Olegovna Zekiy}

I.M. Sechenov First Moscow State Medical University (Sechenov University), Russia

\section{Arkadiy Viktorovich Moiseev}

Kuban State Agrarian University named after I.T. Trubilin, Russia, a.v.moiseev@inbox.ru

Margarita Evgenevna Belomestnova

Russian State University of Physical Education, Sport, Youth and Tourism, Russia

Irina Aleksandrovna Savelyeva

Nosov Magnitogorsk State Technical University, Russia, irina_savelyeva@inbox.ru

Olga Sergeevna Aleynikova

Razumovsky Moscow State University of Technologies and Management, Russia

The purpose of the research is to analyse the use of active learning technologies in training students and to assess the effectiveness of their use in the teaching process in secondary vocational education. In order to verify the effectiveness of the developed pedagogical methods, methods of experimental work and analysis of the obtained data were applied. The authors also used survey and testing methods among students of an educational organization for professional motivation, obtaining a significant amount of data. In order to identify the resulting changes, testing of students was repeated at the final stage of the study. The authors have substantiated the use of active learning technologies in the formation of career motivation of students of secondary vocational education. The essence of technology is in enhancement of the student's position as a subject in the educational process. The effectiveness of pedagogical environment for active learning technologies in the formation of career motivation in secondary vocational education students has been experimentally substantiated.

Keywords: career motivation, motives, professional education, technology, skills

Citation: Bochkareva, T. N., Akhmetshin, E. M., Zekiy, A. O., Moiseev, A. V., Belomestnova, M. E., Savelyeva, I. A., \& Aleynikova, O. S. (2020). The Analysis of Using Active Learning Technology in Institutions of Secondary Vocational Education. International Journal of Instruction, 13(3), 371-386. https://doi.org/10.29333/iji.2020.13326a 


\section{INTRODUCTION}

\section{Problem Statement}

In the latest decade, due to the demographic crisis in Russia, the number of students in institutions of secondary vocational education has decreased. According to many statistical studies, students entering vocational education institutions often have low scores at the unified state exam; they lack desire and motivation to strive for knowledge and conscious choice of profession (Veduta, 2018). It should be mentioned that in the modern world, the level of requirements for the training of specialists in both higher and secondary vocational education is growing progressively.

Consequently, the main and key task of educational system is still to make students become competent personnel for the labor market. Of course, to solve the task it is necessary to form a high career motivation level in students (Federal Law, 2016). Therefore, in modern education, active learning technologies are widely used, as they not only foster self-reliance in students, but also form their career motivation (Shindryaev, 2016; Sergunina \& Povalyaeva, 2016; Krasilnikova, 2014).

Career motivation helps to quickly achieve the goals and objectives set for students (Saiphet, 2018).

With regard to the educational activities of students in the secondary vocational education system, career motivation is understood as a set of factors and processes that, being reflected in the consciousness, encourage and direct individuals to study their future professional activities. These factors include: educational system factors; educational environment factors; educational process organization peculiarities; the student's personal features; the teacher's personal features and his attitude towards students; specifics of disciplines and professional modules mastered by students, etc.

In the structure of career motivation, a positive attitude towards the profession plays an important role, since this attitude is related to the ultimate goals of education. The student's conscious choice of profession will have a positive impact on his professional training level (Filippov, 2015).

There are a number of factors reducing career motivation. The previous idea of their future profession might not correspond to what the student has learned about it in Technical School. In addition, the student may be unprepared for systematic and intense learning activities. Failure to understand the place of a particular discipline in the integrated system of vocational training can lead to a negative attitude towards it, despite general interest in learning. Hence, there is a necessity of focusing vocational training on increasing the personal activity of students (Chan et al., 2015), (Bochkareva et al., 2018).

To date, there are many ways to enhance the learning process through the introduction of active learning technologies (Llorens et al., 2017; Oliveira, 2015; Akhmetshin, et al., 2019). Active learning is the process of activating the learning and cognitive activity of students using various pedagogical techniques, organizational and managerial tools and methods. It follows that active learning technologies are a way to organize the learning 
process, which is aimed at the active engagement of the learner in the cognitive process, his interaction with the teacher, independent and proactive student participation in the learning process (Gromov, 2015).

The use of active learning technologies solves the following tasks:

1. Carrying out the development and improvement of the processes of memory, attention and thinking in the educational institution students;

2. Developing students' skills and abilities to analyze and synthesize difficult situations, as well as skills to single out the most important things, to find solutions and ways out of uncertain situations;

3. Developing the skills of productive communication, interaction of all the educational process participants in the course of learning;

4. Developing the students' ability to formulate their thoughts clearly, to make their own decisions independently, to express personal opinion, to argue and defend it (Filippov, 2015).

As can be seen from the above classification of tasks, the main direction of the learning process with the use of active learning technologies is the ability to generate in students the maximum possible level of knowledge and skills, to promote the development of thinking and memory processes, as well as the ability to independently find the necessary solutions.

The purpose of the research is to analyze the current use of active learning technology and assess the effectiveness of their use in the career motivation formation in secondary vocational education institutions.

The research hypothesis is that the use of active learning technologies, active interaction with the external environment results in the improvement of the educational process and increases the career motivation level in students of secondary professional organizations.

\section{LITERATURE REVIEW}

The students' career motivation formation based on the active learning technology is currently acquiring new features of development. The modernization of Russian education requires a change not only in the educational standard, but also in the thinking of students (Khoroshikh, et al., 2018). The motivation of students largely depends on the quality of education. The introduction of active learning technology can develop such abilities as critical thinking, interest in learning, the desire for knowledge and selfimprovement (Oliveira, 2015).

A student's success is determined by the learning environment and the methods of its implementation (Ololube, et al., 2018). Thanks to the active learning technology, students easily acquire professional skills, and the speed and simplicity of the educational process helps to increase motivation among students. Thus, secondary vocational education can reach the advanced level. (Llorens et al., 2017). 
The main barrier to achieving the goal is passive technological integration, a kind of barrier that prevents the effective use of the latest educational technologies (Laine, \& Nygren, 2016). In the modern world, active education technology manifests itself as a diverse, quality learning process, and implies integration into the vocational training system of students (Cardullo, et al., 2017).

The active learning technology forms a student's career motivation that awakens students' interest in the chosen profession, contributes to improvement of their knowledge, skills, competitiveness and the creation of qualified personnel who will be in demand in the labour market (Billsberry, \& Brown, 2017).

Thus, a review of contemporary literature suggests that research on the use of active learning technologies in preparing students is widely discussed in Internet sources and various scientific journals.

\section{Research Organization}

For the experimental substantiation of the effectiveness of active learning technology in the formation of career motivation of secondary vocational education students during 2017-2018, the authors have conducted research work. For the study, 40 fourth-year students (as of September 1, 2017) were chosen in the area of preparation for "Economics and Accounting" of the secondary vocational education institution Kama State Automotive Technical School named after L.B. Vasiliev. The students are residents of Naberezhnye Chelny, Elabuga, and other cities and districts of the Republic of Tatarstan (Russian Federation). In the experimental group, consisting of 20 students, teachers used active learning technology on the training subjects of the economic cycle Enterprise Economy and Fundamentals of Accounting. These subjects are quite difficult among the basic academic disciplines in the curriculum of the students in the area of Economics and Accounting. In addition, the study involved 14 teachers of economic cycle disciplines.

In the control group consisting of 20 students, in teaching the disciplines Enterprise Economy and Fundamentals of Accounting traditional methods were applied according to the work program of the subjects, approved by the Technical School Department of economic disciplines.

Thus, the study summarizes the ideas of the use of active learning technologies in the formation of career motivation of secondary vocational education students, the essence of which lies in the creation of relevant pedagogical environments in the educational process using active learning technologies.

The research presented in this paper was conducted at Kama State Automechanical Technical School named after LB Vasiliev, the state autonomous secondary vocational educational institution in the town of Naberezhnye Chelny, and included:

- studying the conditions for the career motivation formation in students of professional educational institutions based on active learning technologies;

- studying the career motivation level in students of an educational institution; 
- developing and testing integrated pedagogical environments for the use of active learning technologies in Technical School education to form career motivation in students.

Verifying the effectiveness of the developed pedagogical environments was performed by methods of experimental work and analysis of the obtained data. Methods of questioning and testing were also used, providing a significant amount of data.

\section{METHOD}

The methodology of this research is based on modern methods widely used by foreign and Russian authors in pedagogy, psychology, sociology, and other sciences. The study was based on the methodology of the educational process and the didactics of learning technologies (Ololube, 2018), and on practical results obtained in the development and implementation of active learning technologies.

As a methodological substantiation of the study, the activity approach together with competence-based, person-centered and innovative approaches is considered providing a higher career motivation level, including the ability to prepare and implement the student's active position in the educational process (Korzh, 2013).

The authors have analyzed the current use of active learning technology carried out by the teaching staff in the organization of secondary vocational education - the town of Naberezhnye Chelny "Kama State Automotive Technical School named after L. B. Vasiliev". The training in the Technical School takes place in specially equipped classrooms equipped with specialized study guides, technical teaching aids (interactive whiteboards, workstations with individual computers, calculating tools, projectors). The pedagogical staff ensures the timely operation of these technical media and eliminates possible malfunctions in the process. Thus, we can say that the KSATS in the town of Naberezhnye Chelny provides all the opportunities for using interactive learning technologies and the effective organization of classes during the educational process.

Nevertheless, even the maximum equipment with the latest technical devices does not provide the learning process with the necessary training quality level for students, but is only a means of reinforcing during the transfer of knowledge and information by the teacher. To obtain the necessary effect of students mastering knowledge at KSATS in the city of Naberezhnye Chelny, in the learning process, the teachers carry out the methodological training process and choose one or another active learning technology based on the level of training, interests and capabilities of the students, their own ability to apply one or another active learning technology, based on skill and experience level. To determine the place of active learning technologies in the structure of classes at KSATS in the city of Naberezhnye Chelny, we consider in more detail the organization of the learning process and its components.

Based on the principles of modern education, the priority direction at KSAC in the city of Naberezhnye Chelny is the organization of the educational process with the possibility of cooperation and communication between teachers and students. The teacher organizes collective and independent work, uses various technical and 
interactive teaching aids, applies problem-based teaching technologies, methods based on explaining and illustrating, searching and solving various problems. During the learning process, the teacher also carries out the control function, through various forms of testing: organization of tests, homework, verification work, verbal answers during the classes, quises.

During the organization of the educational process in economic disciplines, the teacher carries out his work mainly in the traditional form, namely: various conversations, discussions, stories and explanations of new material, based on printed manuals (books, textbooks, reference books), Internet resources. The organization of this type of activity, unfortunately, reduces the level of students' involvement, their participation in the learning process, reduces their activity and leads to fatigue. All this happens due to the fact that students do not have time to perceive the transmitted information, reflect on it, analyze and compare with previously obtained data, as they devote a lot of time to listening to monotonous speech and recording new material. One way or another, this significantly affects the effectiveness level of the education and training process for students.

Evaluation of the effectiveness of the active learning technology use in the formation of career motivation in the Technical School was carried out among students of two experimental groups: 246P second year students in the course of "Economics and Accounting" and $440 \mathrm{X}$ fourth year students in the training course of "Engineering Technology". The total number of students in both groups is 50 people (27 and 23, respectively), the total number of girls is 28 ( 25 and 3, respectively), the total number of boys is 22 ( 2 and 20, respectively). During the training, the students have developed friendly relations in the team. The learners are ready to help each other at any moment, they successfully complete teamwork. Students easily, freely, quickly, with high efficiency coordinate their actions. The existing separate groups actively interact with each other, maintaining group unity. Students of both groups are respectful to teachers, show responsibility in fulfilling their assignments and requests. In both groups, the leader is the headman - the most responsible, communicative, initiative student. Half of the students perform at a high level. From the first day of training, the students of both groups strive to join creative vocal and dance groups. Two young men play in the Tekhnaz Club of Humor team. Both girls and boys are actively involved in sports and keep a healthy lifestyle. Some of them attend sports sections at the Technical School.

Within the activity approach paradigm, each lesson in the experimental group, in accordance with a particular topic, used various active learning technologies. Thus, the first and second lecture classes on the topics Essence, Concept, Subject and Object of Economics, Economic Efficiency used the technology of group activity. At this stage, based on the application of the panel discussion method, acquaintance with the group took place, as well as reproduction of material previously studied by students, studying of new material, group analysis and synthesis of information. This technology has made it possible to study group values, the level of group interrelation and cohesion in work, to reveal among the group of students those who are able to cope with the work independently, group leaders, and students lagging behind in the level of training. 
At tutorial classes three and four dealing with the topics of Economic Benefits, Money and its Functions, Investments, the technology of problem-based learning was introduced. At this stage, before the lesson, the students needed to familiarize and master the lecture material provided by the teacher for independent study. At the beginning of the class, the students took their places and began watching the video lesson, dedicated to the basic concepts, functions, definitions and classifications by topic, so the students could reproduce the lecture material. Next, the audience was asked questions on the compendium studied at home, with the discussion of material not clear to the students.

The fifth and sixth tutorials were dedicated to the use of technology of project-based teaching methods on the topics Banking System, Inflation, Tax System. At this stage, each student was offered the choice of a topic for further independent study and writing a project on the banking system of a particular country, or a specific tax applied in the Russian Federation. After training, the students delivered a public speech to the audience on their projects, supported by video and audio material. This approach helped identify each student's level in the ability of independent study of the material, highlighting the main aspects, correctness, brevity and accuracy of data presentation.

The seventh workshop on the topic Unemployment and its Types was organized in the form of the business game Job Search. The goal of the game was as follows: with the help of modeling possible situations on the labour market and in job placement, to teach the skills of effective and correct behavior, accurate preparation of a resume in accordance with the requirements. The relevance of the game was in showing the need in modern conditions of competition in the labor market to defend ones interests in the job placement process, to be able to show oneself as an employee. The number of participants in the game was 22,2 of which being human resources managers, 4 jury members, 2 assistants, 14 players. The essence of the game was as follows: during the game stages, each player provides a prepared summary to the jury members; then, interacting with the personnel manager, and with the staff, he makes a telephone conversation on the topic of the job; the jury assesses the style and appearance of the clothes according to the established requirements; each participant finally has an interview when applying for a job position. Based on the assessments of the jury, the final results are displayed and 3 best participants are selected. At the end of the game, the winners are awarded with a work record and diplomas of the Best Candidate 2018. This game has allowed revealing the potential of many students, showing talents and skills of the students, overcoming psychological barriers in the process of work, identifying mistakes and mastering the skills of resume writing.

The final lecture class on the topic State Regulation of the Economy was conducted using health-saving technologies. This stage involved the study of various mechanisms and levers by which the state regulates the economic situation of the country, it reflected all environmental problems, and showed their impact on the environment. Also during the lecture, great attention was paid to the students' activity, periodic physical exercises, short psychological trainings were held, with the purpose to reduce stress during the training session, to build cohesion, to obtain information about each other, to develop 
observation, attention, decrease in thought processes and brain activity, physical relaxation of the body, the removal of emotional stress. The following trainings were conducted: Pass on to Another, Window, Sixth Sense. Each of these trainings took place after a certain period of time (20 minutes). Owing to the psychological trainings, the efficiency and activity of students, attentiveness in the performance of tasks and motivation for further work noticeably increased.

\section{FINDINGS}

Based on experimental methods using diagnostic tools to test the level of career motivation (L. A. Vereshchagin), monitoring was carried out at the ascertaining stage (September - October 2017) and the control stage (May - June 2018).

The diagnostics included the identification of the level of active learning technologies used at various stages of the educational process in Kama State Automechanical Technical School named after LB Vasilyev in the city of Naberezhnye Chelny. The survey was conducted among the teaching staff engaged in training students in economic disciplines. The use of active learning technologies was considered, such as problembased learning technologies, project method technologies, team work technologies, role playing technologies, information and communication technologies. The respondents had teaching experience. 118 teachers attended the survey. The survey was performed within one working day. The survey used the facilities of Kama State Automechanical Technical School named after LB Vasilyev in the city of Naberezhnye Chelny. For systematization and analysis of the survey results, a tabular Microsoft Excel processor was used. For conducting the survey and analyzing its results, written permission was obtained from the respondents to use their personal data. There were no those who refused to take part in the survey. The margin of error was $5 \%$.

The survey was conducted anonymously and included 10 questions concerning the use of active learning at various stages of the educational process at Kama State Automechanical Technical School named after LB Vasilyev in the city of Naberezhnye Chelny (Table 1).

Table 1

Questions to Analyze the Level of use of Active Learning Technologies in Studying Economic Disciplines

\begin{tabular}{|c|c|}
\hline Question & Answer Options \\
\hline Personal Data (group, age, gender) & $\begin{array}{l}\text { Age: } \\
\text { Gender: } \\
\text { Teaching experience: }\end{array}$ \\
\hline $\begin{array}{l}\text { 1. Do you know anything about such active } \\
\text { learning technologies as: problem-based learning, } \\
\text { theory of inventive problem solving technology } \\
\text { (TIPS), technologies of project-based teaching } \\
\text { methods, health-saving technologies, etc.? }\end{array}$ & $\begin{array}{l}\text { a) yes } \\
\text { б) no }\end{array}$ \\
\hline $\begin{array}{l}\text { 2. Do you apply the above technologies in your } \\
\text { teaching activities and how often? }\end{array}$ & $\begin{array}{l}\text { a) do not apply at all } \\
\text { b) apply, but very rarely } \\
\text { c) have not heard about such active learning } \\
\text { technologies } \\
\text { d) apply quite often }\end{array}$ \\
\hline
\end{tabular}

International Journal of Instruction, July $2020 \bullet$ Vol.13, No.3 


\begin{tabular}{|c|c|}
\hline $\begin{array}{l}\text { 3. Do you consider it necessary to use interactive } \\
\text { learning tools? }\end{array}$ & $\begin{array}{l}\text { a) yes } \\
\text { б) no }\end{array}$ \\
\hline 4. YOU spend the main part of the lesson as: & $\begin{array}{l}\text { a) theoretical lecturing } \\
\text { b) role playing } \\
\text { c) discussion }\end{array}$ \\
\hline $\begin{array}{l}\text { 5. Do you consider studying a lecture material by a } \\
\text { student independently more effective than joint } \\
\text { study? }\end{array}$ & $\begin{array}{l}\text { a) yes } \\
\text { б) no }\end{array}$ \\
\hline $\begin{array}{l}\text { 6. Do you succeed in concentrating students' } \\
\text { attention on you during the class? }\end{array}$ & $\begin{array}{l}\text { a) yes } \\
\text { б) no }\end{array}$ \\
\hline $\begin{array}{l}\text { 7. Do you like it when students offer their own } \\
\text { solutions to the problem set, or do you offer only } \\
\text { one algorithmic course of work? }\end{array}$ & $\begin{array}{l}\text { a) yes, I like students offering their own solutions } \\
\text { б) no, I would rather let everyone follow the } \\
\text { algorithm to prevent mistakes }\end{array}$ \\
\hline $\begin{array}{l}\text { 8. Do you interact with students during classes, } \\
\text { talk to them about the topic, are you interested in } \\
\text { their opinions? }\end{array}$ & $\begin{array}{l}\text { a) yes, it is very important } \\
\text { б) no, it relaxes them and prevents them from } \\
\text { assimilating information }\end{array}$ \\
\hline $\begin{array}{l}\text { 9. Do you find the student's search for additional } \\
\text { information on the topic positive? }\end{array}$ & $\begin{array}{l}\text { a) yes, it develops him as an individual } \\
\text { b) no, it clogs his thinking with superfluous } \\
\text { information that hinders the absorption of the } \\
\text { necessary. }\end{array}$ \\
\hline $\begin{array}{l}\text { 10. Being offered to conduct an open class with } \\
\text { the use of active learning technologies introducing } \\
\text { various technical and interactive tools, will you } \\
\text { undertake such work? }\end{array}$ & $\begin{array}{l}\text { a) no, because it takes a lot of time and effort } \\
\text { b) no, because of my incompetence } \\
\text { c) yes, I like giving classes in an unconventional } \\
\text { form, it allows me to develop as a person and } \\
\text { cope with new obstacles. }\end{array}$ \\
\hline
\end{tabular}

Based on the analysis of the questionnaires, the results of using active learning technologies by Technical School teachers at various stages of the educational process were formed. The results of this study are as follows (Table 2):

Table 2

The Results of the use of Active Learning Technologies by Technical School Teachers at Various Stages of the Educational Process at the Ascertaining and Control Stages (in $\%)$

\begin{tabular}{lll}
\hline Use of active learning technologies & $\begin{array}{l}\text { Ascertaining stage } \\
\text { of research }\end{array}$ & $\begin{array}{l}\text { Control stage of } \\
\text { the research }\end{array}$ \\
\hline at the phase of updating knowledge & $12 \%$ & $27 \%$ \\
\hline at the phase of acquiring new knowledge & $10 \%$ & $25 \%$ \\
\hline at the phase of the new material consolidation & $8 \%$ & $32 \%$ \\
\hline at the phase of the educational process reflection & $11 \%$ & $33 \%$ \\
\hline
\end{tabular}

The use of active learning technologies averages $12 \%$ at the phase of updating new knowledge; it is about $10 \%$ at the phase of mastering new material during the learning process, $8 \%$ at the new material consolidation phase, and only $11 \%$ at the learning process reflection stage.

For visual presentation of the results of the survey, charts were constructed (Figure 1): 


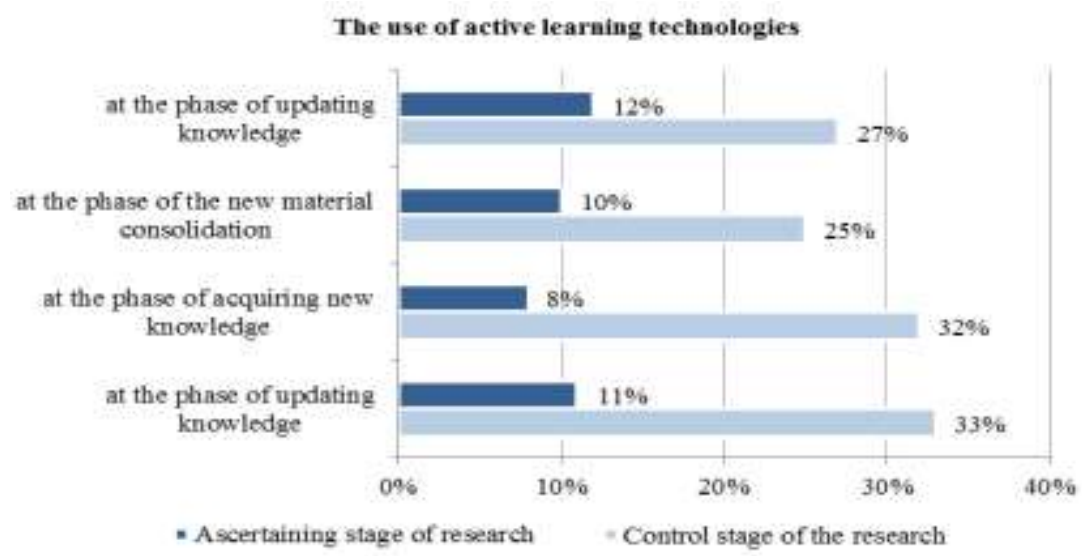

Figure 1

Dynamics of the Proportion of Active Learning Technologies usage at Various Stages of the Educational Process (in \%)

As a result of the study, the authors have revealed that in the Kama State Automechanical Technical School named after L.B. Vasiliev, the application of active teaching technologies by teachers of economic disciplines is changing significantly in favor of increasing the time of such classes.

The results of the diagnostic study of students in the ascertaining and control stages appear in table 3.

Table 3

Indicators of the Studying Motives for Students in the Experimental and Control Groups at the Ascertaining and Control Stages (in \%)

\begin{tabular}{lllll}
\hline Motives & \multicolumn{3}{l}{ Ascertaining stage } & Control stage \\
\cline { 2 - 5 } & $\begin{array}{l}\text { Experimental } \\
\text { group }\end{array}$ & $\begin{array}{l}\text { Control } \\
\text { group }\end{array}$ & $\begin{array}{l}\text { Experimental } \\
\text { group }\end{array}$ & $\begin{array}{l}\text { Control } \\
\text { group }\end{array}$ \\
\hline Social significance of labour & $55 \%$ & $10 \%$ & $40 \%$ & $40 \%$ \\
\hline Personal labour & $15 \%$ & $30 \%$ & $25 \%$ & $20 \%$ \\
\hline Self-affirmation in labour & $20 \%$ & $10 \%$ & $30 \%$ & $35 \%$ \\
\hline Professional skill & $10 \%$ & $40 \%$ & $5 \%$ & $5 \%$ \\
\hline
\end{tabular}

At the ascertaining stage the Technical School teachers concentrate on the principles of using traditional teaching methods when studying economic disciplines, with minimal reliance on technologies and methods of active learning; while at the control stage there is an increase in the proportion of active learning technologies used in teaching economic disciplines from one quarter to one third of the total number of teachers.

There are diagrams constructed for a visual representation of the diagnostic study of students in the ascertaining and control stages (Figure 2): 


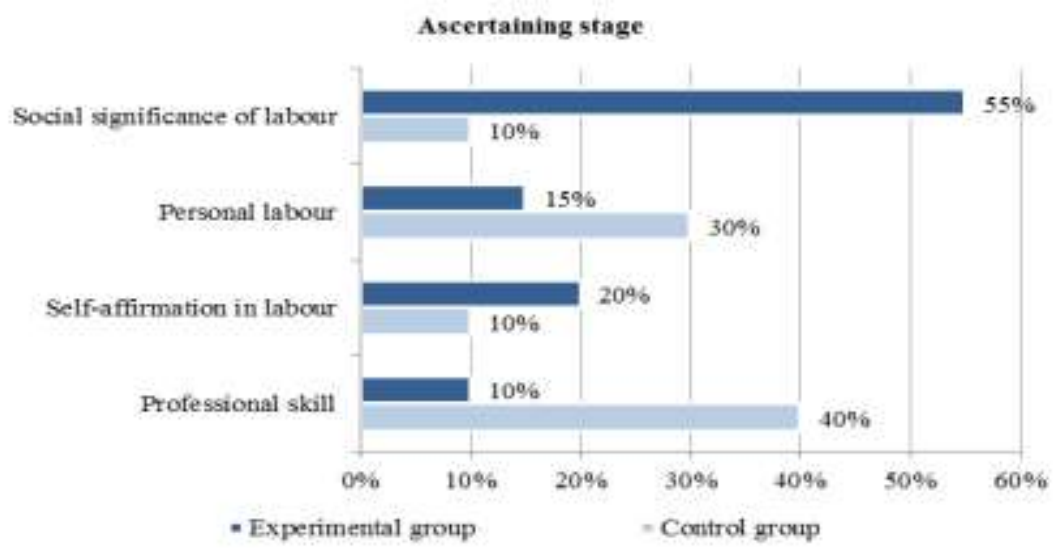

Figure 2

Percentage Ratio of the Studying Motives for Students of the Experimental and Control Groups at the Ascertaining Stage

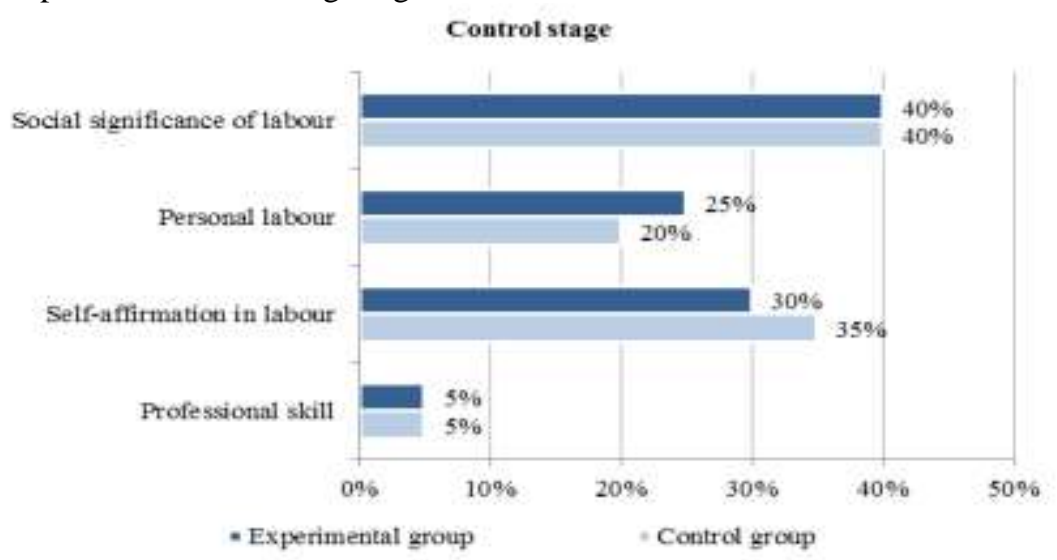

Figure 3

Percentage Ratio of the Studying Motives for Students of the Experimental and Control Groups at the Control Stage

The results of the research conducted among students has shown that for practicing their professional activity its social significance is of great importance. This means that the majority of students believe that their work should be useful to society and recognized by them. As the second in the ranking of the motives of learning, students mention the self-affirmation motives in work. It is important for students that their future profession satisfies their interests and needs and helps them to realize their abilities. The motive of respondents' own work ranks third, that is, the nature of the work itself is more important for these students than other factors. Motives of professional skill occupy the last place among the respondents. Most likely, this is caused by the age characteristics of

International Journal of Instruction, July $2020 \bullet$ Vol.13, No.3 
students and the insufficient amount of acquired knowledge, skills, abilities and competencies in the profession (Bochkareva et al., 2018).

During the study of career motivation of students at the control stage, it was revealed that as a result of the activities of the experimental group of students, the motives of professional skill became the prevailing motives of professional activity. An important aspect is the reduction in the number of students with the prevailing motives of the social importance of labour.

In their study, the authors used the mathematical-statistical method; it was used to make a quantitative analysis of the experimental data. The designation $\mathrm{X}$ was selected to compare the experimental groups and process the material obtained.

The mathematical and statistical analysis of $X$ (with $p=0.05$ ) has shown:

- insignificant reliability of differences between experimental and control groups in all indicators at the ascertaining stage, which confirms the correct choice of statistically identical groups for research activities;

- mathematically significant reliability of differences between the experimental and control groups in all indicators at the control stage.

Thus, based on the obtained mathematical-statistical data of the experiment and a comparative study between the values in the groups under study, we have revealed:

- the use of active learning technologies to a greater extent contributes to the formation of career motivation of students, and to the formation of their need for personal activity in the educational process;

- the organization of a pilot study based on the Technical School has significantly increased the use of active teaching technologies by teachers in the educational process, increasing also their interest in non-traditional forms of organizing classes;

- traditional forms of teaching students underlying the work programs of academic disciplines have less influence on the formation of students' career motivation.

The scientific novelty of the study is as follows:

- we have clarified the intrinsic and meaning characteristics of active learning methods;

- we have carried out an assessment of the use of active learning technologies;

- we have studied the problems encountered in the implementation of active learning technologies in the Technical School

- we have developed recommendations to eliminate errors and correct these problems.

The practical significance of the study lies in the fact that the recommendations on the application of active learning technologies can be used by a teacher of a professional educational organization to increase the effectiveness of training, by activating and motivating students to the learning process. 


\section{DISCUSSION}

The problem of using active teaching methods in order to improve academic performance is widespread among modern scientists' research papers (Khoroshikh et al., 2018; Morosan et al., 2017). Scientists C. Morosan, M.Dawson, \& E.A.Whalen (2017) have proposed using a new course based primarily on active study of the subject by 230 undergraduate students. The results have shown improvements in technical skills, leadership, teamwork, communication, openness to diversity and creativity.

There is a well-known study on the implementation of active learning methods using MOOCs (mass open online courses) (Saalman, 2016). Chalmers Technical University (Chalmers) has joined the MOOCs movement and has been a partner in the edX platform since 2014. As shown in the Chalmers event study, MOOCs can be used to support active learning in technical education. Active learning is one of the approaches to student teaching, where they learn through reading, observing, listening, writing, discussing and reflecting, which makes it natural to think of MOOC as a valuable resource for active learning.

Scientists note the importance of the role of the teacher in active study. Mikalayeva, L. (2016) states that active learning is most productive with the teacher creating and consistently enforcings a stable and clear structure of rules. Active learning methods often reach higher levels of motivation, thanks to the greater efforts of students, higher success rates within a competitive collaborative set-up, and greater student participation rate in the whole process. A high level of motivation may improve the quality and depth of studying. However, increased motivation probably creates several problematic overmotivations, confusion, alienation, and hostility — which can only be best resolved by the teacher.

The study by P. Saiphet (2018) showed that active learning methods influence the motivation of university students. In 2018, Thai university students studying English were offered active learning methods. The results showed that at the end of the semester, the motivation in language learning had significantly increased among those taking part in studying in an active way.

In the research by B.N. Kireev (2017) the definition of active learning method was given: it is a form of interaction between students and a teacher in a classroom, which implies student - teacher and student - student communication. The author shows that one of the most promising forms of active learning is e-learning. Most often e-learning is used along with traditional classroom education. This type is called mixed learning. The use of electronic educational resources (EER) in Russian universities, especially in the system of pedagogical education, has taken an increasingly practical form, while there is a shortage of theoretical research. The author pays special attention to the use of electronic educational resources, showing positive results in the preparation of future bachelors. In this case, though, the author does not put a student in a subject position in the educational process.

The theory of mixed learning is also supported by S. Alhazbi (2015). The authors have designed and implemented a mixed programming learning environment that supports 
collaborative learning, provides a high level of student - teacher interaction, giving timely feedback to students, and supports students' reflective practice. To assess the effectiveness of the approach, a comparison of students' speeches was made by other students. The results show that the above approach has a positive effect on student motivation and work.

The work by S. Bishara (2018) also confirms the hypothesis that active learning will lead to increased motivation in the learning process compared to traditional learning. The differences between the two approaches for teaching mathematics to handicapped learners were explored: active learning as opposed to traditional teaching appeared to involve students more directly in their own learning process promoting both joint learning and traditional learning. Forty pupils with problems in specialized education classes in a regular elementary school participated in the study. In two classes, the active leaning approach was used to teach mathematics, and in two classes, the traditional approach was used. The results indicate that the motivation and performance of the students in active learning classes to study mathematics were higher than in traditional classes.

Researchers C.A.T. Cicuto, \& B.B. Torres (2016) support the above hypothesis: student motivation in an active learning environment is higher. These results demonstrate that the active learning environment has had a positive effect on student motivation.

\section{CONCLUSION}

Testing the technology of active learning in the disciplines of the economic cycle, aimed at the career motivation formation, has confirmed its effectiveness in the following aspects: the formation of the motive of acquiring professional skills in the educational process, caused by the desire to apply knowledge and skills to gain professional competencies; the formation of the motive of self-assertion in labour. This fact indicates a great desire of students to know their personal capabilities in the process of educational and professional activities.

The practical significance of the study lies in the fact that the use of active learning technologies enables students to form personal orienting qualities, the ability of instant decision-making, independence, proactive approach, creativity, ability for teamwork, competitiveness. All this allows students who have completed secondary vocational education to easily get a profession in the specialty.

The above makes it possible to conclude that the introduction of active methods progressively affects the change in the system of secondary vocational education, and does it the best way, since their use significantly increases the career motivation of students, and as a result, the academic performance improves.

Summing up, we can conclude that the use of active methods contributes to improving the quality of education, making students more motivated and interested in the subjects they study, the students strive to attend full-time classes. It is also safe to say that it is necessary to focus not on some elements of the motivation of students' learning 
activities, but on identifying the circumstances and patterns of improving the level of motivation, which will help create a holistic picture of this task.

\section{REFERENCES}

Alhazbi, S. (2015). Active blended learning to improve students' motivation in computer programming courses: A case study. M Abdulwahed et al. (Eds.), Advances in engineering education in the middle east and north Africa (pp. 187-204). Springer.

Akhmetshin, E. M., Ibatullin, R. R., Gapsalamov, A. R., Vasilev, V. L., \& Bakhvalov, S. Y. (2019). Audiovisual aids application in the secondary-level vocational education establishments: efficiency analysis and assessment. International Journal of Educational Management, 33(2), 1-20. doi:10.1108/IJEM-02-2018-0082.

Billsberry, J., \& Brown, K. G. (2017). The medium is the message: On the emergence of autonomous learning, MOOCs, and technology-enabled active learning. In J. E. Ellingson, \& R. A. Noe (Eds.), Autonomous learning in the workplace (pp. 237-260). New York: Routledge.

Bishara, S. (2018). Active and traditional teaching, self-image, and motivation in learning math among pupils with learning disabilities. Cogent Education, 5(1), 1436123. https://doi.org/10.1080/2331186X.2018.1436123.

Bochkareva, T.N., Litvinenko, S.V., Guseva, L.V., Tonkikh, A.P. (2018). Evaluation of the formation of professional motivation of students of secondary vocational education.Worldof Science. Pedagogy and Psychology, 6(2), 91PDMN218.

Cardullo, V. M., Wilson, N. S., \& Zygouris-Coe, V. I. (2017). Enhanced student engagement through active learning and emerging technologies. In M. Khosrow (Ed.), Student engagement and participation: Concepts, methodologies, tools, and applications (pp. 399-417). IGI Global.

Chan, K., Cheung, G., Wan, K., Brown, I., \& Luk, G. (2015). Synthesizing technology adoption and learners' approaches towards active learning in higher education. Electronic Journal of e-Learning, 13(6), 431-440.

Cicuto, C. A. T., \& Torres, B. B. (2016). Implementing an active learning environment to influence students' motivation in biochemistry. Journal of Chemical Education, 93(6), 1020-1026. doi:10.1021/acs.jchemed.5b00965.

Federal Law. (2012 December, 2). Legal reference system "Consultant Plus". Retrieved from http://www.consultant.ru/document/cons_doc_LAW_140174/.

Filippov, L. V. (2015). The use of active forms and learning methods in the teaching of the course "Theory and technology of children's speech development". Modern High Technologies, 12, 561-564.

Gromov, O. A. (2015). Modern psychological and pedagogical technologies used for career motivation in learning. Scientific Almanac, 10-2(12), 139-142.

Khoroshikh, P. P., Sergievich, A. A., \& Platonova, R. I. (2018). Development of students' critical thinking by active and interactive training methods. TEM Journal, 7(4), 787-790. doi:10.18421/TEM74-14. 
Kireev, B. N. (2017). The use of active teaching methods in bachelor training. Espacios, $38(56)$.

Korzh, Yu. V. (2013). The research of students professional activity motivation in the university of pharmacy. Management, Economics and Quality Assurance in Pharmacy, $3(29), 36-40$

Krasilnikova, O. A. (2014). The problem of the development of motivation of educational and professional activities of Polytechnic Technical School students. Psychology, Sociology and Pedagogy, 10(37).

Laine, T. H., \& Nygren, E. (2016). Active and passive technology integration: A novel approach for managing technology's influence on learning experiences in context-aware learning spaces. Technology, Pedagogy and Education, 25(1), 19-37.

Llorens, A., Berbegal-Mirabent, J., \& Llinàs-Audet, X. (2017). Aligning professional skills and active learning methods: An application for information and communications technology engineering. European Journal of Engineering Education, 42(4), 382-395.

Mikalayeva, L. (2016). Motivation, ownership, and the role of the instructor in active learning. International Studies Perspectives, 17(2), 214-229. doi:10.1093/isp/ekv001.

Morosan, C., Dawson, M., \& Whalen, E. A. (2017). Using active learning activities to increase student outcomes in an information technology course. Journal of Hospitality and Tourism Education, 29(4), 147-157. doi:10.1080/10963758.2017.1382369.

Oliveira, A. M. (2015). Simple ways to facilitate active learning in hands-on electrical engineering technology courses. Paper presented at the 122nd ASEE Annual Conference and Exposition: Making Value for Society.

Ololube, N. P. (2018). Active learning application of technology tools and services and increased student achievement: Online and blended learning environments in higher education institutions. In M. Khosrow (Ed.), Online course management: Concepts, methodologies, tools, and applications (pp. 162-183). IGI Global. doi:10.4018/978-15225-5472-1.ch009

Saalman, E. (2016). Active learning with the use of MOOCs at Chalmers university of technology - experiences, challenges and future. Paper presented at the International Symposium on Project Approaches in Engineering Education, 6 132-139.

Saiphet, P. (2018). The effects of active learning on Thai university students' motivation to learn English. International Journal of Interdisciplinary Educational Studies, 13(4), 37-50. doi:10.18848/2327-011X/CGP/v13i04/37-50

Sergunina S.V., \& Povalyaeva N.G. (2016). The development of the motivation for the professional activity of the future teacher of physical

Shindryaev, I.V. (2016). Increasing the motivation of students' learning activities through active methods and learning technologies. Electronic Scientific and Educational Journal VSPU "Edges of Knowledge", 2(45).

Veduta, O. V. (2018). Peculiarities of the career motivation formation in students of secondary vocational education institutions. Professional education in Russia and abroad, 1(29), 63-70. 